\title{
Protein S Deficiency - An Uncommon Cause with Common Presentation
}

\author{
Kora $\mathbf{N}^{1}$, Das $\mathbf{R}^{2}$, Som $\mathbf{S}^{3}$, Laha $\mathbf{S}^{4}$, Bannerji $\mathbf{N}^{5}$, Rana $\mathrm{KS}^{6}$
}

\begin{abstract}
Stroke in child poses a major health problem. Thrombophilic factors have been implicated in 4-8\% of young stroke worldwide. Protein $\mathrm{S}$ deficiency is a very rare cause of stroke. A few cases have been reported in literature. We are reporting a rare case of protein $\mathrm{S}$ deficiency causing stroke in a two year old child.
\end{abstract}

Key words: Stroke, Thrombophillic factors, Protein S deficiency

\section{Introduction}

Ctroke or cerebro-vascular accident poses a major health problem. Thrombophilic factors have been implicated in $4-8 \%$ of young stroke worldwide ${ }^{1}$. Protein $\mathrm{S}$ is a naturally occurring vitamin $\mathrm{K}$ dependant protein, which in conjunction with active protein $\mathrm{C}$ inhibits the clotting cascade. Protein $S$ deficiency is known to be of clinical significance in patients with deep venous thrombosis or pulmonary emboli. The incidence of deep vein thrombosis is one episode for every 1000 persons. Protein S deficiency is found to be associated with cerebro-vascular occlusion, although exact role is controversial. Till now no case has been reported having protein $\mathrm{S}$ deficiency presenting as proptosis followed by hemiplegia. So we want it to bring into the notice of every clinician.

\section{The Case}

Dipali Tudu, a two year old female child with body weight of 8 kgs was admitted in our institution with high grade fever for three days and unilateral proptosis of the right eye. She had history of development of furuncle over right side of nose two days before development of fever. There was no contact history of TB.

On examination, surface temperature was raised $\left(103^{\circ} \mathrm{F}\right)$. Proptosis was noticed on right eye, pupil was normal in size, reacting normally to light, while left eye was normal on examination. Heart rate-110/min,Rrespiratory rate $-28 / \mathrm{min}$, Blood pressure of $90 / 60 \mathrm{mmHg}$. On auscultation the chest was clear. There were no associated abnormal neurological signs.

For Orbital cellulitis of right eye and high grade fever, the patient was put on intravenous antibiotics, antipyretics and other supportive management. On the second day of admission, patient
'Dr. Nabanita Kora, Senior Resident, MBBS, MD, ${ }^{2} \mathrm{Dr}$. Rajib Das, RMO, MBBS, DCH, MD, ${ }^{3}$ Dr. Sabyasachi Som, Associate Professor, MBBS, MD, ${ }^{4}$ Dr. Sumanta Laha, Assistant professor, MBBS, MD, ${ }^{5}$ Dr. Nayan Bannerji, MBBS, Post Graduate Student, ${ }^{6}$ Dr. Kriti Sundar Rana, MBBS, Post Graduate Student. All from the Department of Paediatrics, Burdwan Medical College and Hospital, Burdwan, West Bengal, India.

\section{Address for correspondence: \\ Dr. Nabanita Kora \\ E-mail: nabanitacmc@gmail.com}

\section{How to cite}

Kora N, Das R, Som S, Laha S, Bannerji N, Rana KS. Protein S Deficiency - An Uncommon Cause with Common Presentation. J Nepal Paediatr Soc 2015;35(2):192-194.

doi: http://dx.doi.org/10.3126/jnps.v35i2.13616

This work is licensed under a Creative Commons Attribution 3.0 License.

(c) (i)

developed left sided complete hemiparesis with UMN type of facial nerve palsy (left).

Baseline investigations were done that revealed $\mathrm{Hb}-11.5 \mathrm{gm} \%, \mathrm{RBC}$ 6.48million/cumm, WBC-17300/cumm (N79,L2,E0,M1,B0), Platelets-4.96 lakhs/ cumm, ESR-75/120 mm fall in $1^{\text {st }}$ hour, PCV$30.2 \%$, MCV-58.6\%, MCH-22.8pg, MCHC$35.5 \mathrm{gm} / \mathrm{dl}$, CRP-65mg/dl, Na-137meq/l, $\mathrm{K}-3.8 \mathrm{meq} / \mathrm{l}$.

Ophthalmological opinion confirmed orbital cellulitis. CT scan revealed increased hypodensity in right parieto-frontal region with obscured adjacent cortical sulci, maxillary antrum/ethmoid. 
$M R I$ and MR angiography showed vaso-occlusive disease by thrombus involving whole of right internal carotid artery. Screening of brain suggested cortical infarction at right frontal and basal ganglia region. Echocardiography (2D) revealed $10 \mathrm{~mm}$ ostium secundum ASD with L-R shunt without any evidence of pulmonary hypertension.

IV antibiotics were continued and aspirin was started along with physiotherapy.

Table 1: Showing results for thrombophilias

\begin{tabular}{|l|c|c|}
\hline Test & Results & Normal Values \\
\hline Protein S function & 30 & $50-140$ \\
\hline Protein C & 84 & $70-140$ \\
\hline Antithrombin III & 120 & $80-120$ \\
\hline $\begin{array}{l}\text { Factor V leiden } \\
\text { mutation }\end{array}$ & $\begin{array}{c}\text { Not } \\
\text { detected }\end{array}$ & - \\
\hline MTHFR gene mutation & $\begin{array}{c}\text { Not } \\
\text { detected }\end{array}$ & - \\
\hline $\begin{array}{l}\text { Prothrombin gene } \\
\text { mutation }\end{array}$ & $\begin{array}{c}\text { Not } \\
\text { detected }\end{array}$ & - \\
\hline $\begin{array}{l}\text { Anticardiolipin } \\
\text { antibody }\end{array}$ & Normal & - \\
\hline Lupus anticoagulant & Normal & - \\
\hline
\end{tabular}

Workup for thrombophilias revealed reduced protein S function 32(50-140), whereas protein C-84 (70-140) and Antithrombin III-120(80-120) level were within normal limit. Factor $V$ Leiden mutation, MTHFR gene mutation and Prothrombin gene mutation were not detected. Anticardiolipin antibody and lupus anticoagulant were within normal limits.

During first two weeks of treatment, the patient gradually became afebrile and began to walk with support regaining lost power and was ultimately discharged after about three weeks when the patient was able to perform her normal daily activities and was asked to come for follow-up.

\section{Discussion}

Stroke in young population has a high incidence of approximately $25-35 \%$, according to some studies in India. Abraham et $\mathrm{al}^{2}$ from Vellore reported an incidence of $25 \%$ in population less than 40 years of age. Munts et $\mathrm{al}^{3}$ reported that idiopathic coagulation disorders were found in about a quarter of young stroke patients, though there was no clear cut data from India. Carod-A et al ${ }^{4}$ studied about ischemic stroke subtypes and prevalence of thrombophilia in Brazilian stroke patients. They examined 130 consecutive young and 200 elderly patients. Prevalence of thrombophilia was respectively: protein $\mathrm{S}$ deficiency (11.5\% versus $5.5 \%)$, protein C deficiency $(0.76 \%$ versus $1 \%)$. They drew a conclusion that prothrombotic conditions were more frequent in of undetermined causes.

The importance of thrombophiolic disorders in arterial stroke has been debatable. Ischemic stroke has been reported as a rare manifestation of protein $S$ deficiency. Girolami et $\mathrm{al}^{5}$ and Sie et $\mathrm{al}^{6}$ were among the first who reported the association of familial deficiency of protein $\mathrm{S}$ as a cause of ischemic stroke in young. Wiesel et al $^{7}$ studied 105 patients with protein $S$ deficiency, out of which 14 had arterial thrombotic accidents involving central nervous system or the myocardium, while most studies revealed a weaker association between the two $0^{8,9,10}$. Douay et al ${ }^{9}$ reported that hereditary deficiencies of coagulation inhibitors are rare in ischemic stroke patients under 45 years and their systematic detection seems to be of poor interest. Mayer et $\mathrm{al}^{8}$ also supported the fact that acquired deficiency of free protein $\mathrm{S}$ is not a major factor for ischemic stroke. There were only few case reports showing association with arterial thrombosis as reported by Ok E J et $\mathrm{al}^{11}$. Pantam $\mathrm{M}$ et al ${ }^{12}$ reported a 20 years old case of protein S deficiency, presented with homonymous hemianopia and decreased sensation in right side of the baby.

In this two year old patient without any risk factors, the factor S deficiency possibly played a role for the internal carotid artery thrombosis. Factor $\mathrm{S}$ deficiency should be considered in venous stroke, recurrent pulmonary embolism, unusual site of venous occlusion, family history of vascular events, and stroke in young population. Aetiology of such vascular events in young must be thoroughly investigated so as to guide prevention and treatment of this devastating disease. Measurement of total and free protein $\mathrm{S}$ levels should be a part of the evaluation for any young adults who has had a stroke.

\section{Conclusion}

Therefore when dealing with a case of stroke in children, protein S deficiency could also be thought of before making proper diagnosis. As protein $\mathrm{S}$ deficiency predisposes to recurrent thrombophilic accidents, long term follow up is required after diagnosis. Early diagnosis and targeted approach can help such patients to prevent recurrent thrombotic episodes. 


\section{References}

1. Sultan A, Malik IH. Recurrent cerebral infarction in young patient: Combined protein Cand S deficiency. J Coll Physicians Surg Park 2013;23(10):8134.

2. Abraham J, Rao PS, Inbaraj SG, Shetty G, Jose CJ. An epidemiological study of hemiplegia due to stroke in South India. Stroke 1970;1:477-81.

3. Munts AG, van Genderen PJ, Dippel DW, van Kooten F, Koudstaal PJ. Coagulation disorders in young adults with acute cerebral ischemia. J Neurol 1998;245(1):21-5.

4. Carod-Artal FJ, Nunes SV, Portugal D, Silva TV, Vargas AP. Ischemic stroke subtypes and thrombophilia in young and elderly stroke patients admitted to a rehabilitation hospital. Stroke 2005;36:2012-14.

5. Girolami A, Simioni P, Lazzaro AR, Cordiano I. Severe arterial thrombosis in a patient with protein $S$ cerebral deficiency (moderately reduced total and markedly reduced free protein S ):A family study. Thromb Haemost 1989;61:144-47.
6. Sie P, Boneu B, Bierme R, Wiesel ML, Grunebaum $\mathrm{L}$, Cazenave JP. Arterial thrombosis and protein $\mathrm{S}$ deficiency. Thromb Haemost 1989;62:1040.

7. Wiesel ML, Borg JY, Grunebaum L, Vasse $M$, Levesque $\mathrm{H}$, Bierme R, Sie P. Influence of protein $S$ deficiency on the arterial thrombosis risk. Presse Med 1991;20:1023-27.

8. Mayer SA, Sacco RL, Hurlet-Jensen A, Shi T, Mohr $J P$. Free protein $S$ deficiency in acute ischemic stroke. A case control study. Stroke 1993;24:224-7.

9. Dovay X, Lucas C, Caron C, Goudemand J, Leys D. Antithrombin,protein C and protein S in 127 consecutive young adults with ischemic stroke. Acta Neurol Scand 1998;98:124-7.

10. Ok EJ, Kim HW, Kim SD et al. Multivessel Thromboembolism. Associated with Dysfunction of Protein. S Ann Rehabil Med 2012;36:414-417.

11. Pantam N, Pulloori M, Alugubelly K. Stroke in Young with Primary Protein-S Deficiency. J Assoc Physicians India 2014;62:74-75. 